\title{
Changes in organic aerosol composition with aging inferred from aerosol mass spectra
}

\author{
N. L. $\mathrm{Ng}^{1}$, M. R. Canagaratna ${ }^{1}$, J. L. Jimenez ${ }^{2,3}$, P. S. Chhabra ${ }^{4}$, J. H. Seinfeld ${ }^{4}$, and D. R. Worsnop ${ }^{1}$ \\ ${ }^{1}$ Aerodyne Research, Inc. Billerica, MA, USA \\ ${ }^{2}$ Department of Chemistry and Biochemistry, University of Colorado, Boulder, CO, USA \\ ${ }^{3}$ CIRES, University of Colorado, Boulder, CO, USA \\ ${ }^{4}$ Department of Chemical Engineering, California Institute of Technology, Pasadena, CA, USA
}

Received: 23 February 2011 - Published in Atmos. Chem. Phys. Discuss.: 2 March 2011

Revised: 28 June 2011 - Accepted: 28 June 2011 - Published: 7 July 2011

\begin{abstract}
Organic aerosols (OA) can be separated with factor analysis of aerosol mass spectrometer (AMS) data into hydrocarbon-like OA (HOA) and oxygenated OA (OOA). We develop a new method to parameterize $\mathrm{H}: \mathrm{C}$ of OOA in terms of $f_{43}$ (ratio of $m / z 43$, mostly $\mathrm{C}_{2} \mathrm{H}_{3} \mathrm{O}^{+}$, to total signal in the component mass spectrum). Such parameterization allows for the transformation of large database of ambient OOA components from the $f_{44}$ (mostly $\mathrm{CO}_{2}^{+}$, likely from acid groups) vs. $f_{43}$ space ("triangle plot") (Ng et al., 2010 ) into the Van Krevelen diagram (H:C vs. O:C) (Van Krevelen, 1950). Heald et al. (2010) examined the evolution of total OA in the Van Krevelen diagram. In this work total OA is deconvolved into components that correspond to primary (HOA and others) and secondary (OOA) organic aerosols. By deconvolving total OA into different components, we remove physical mixing effects between secondary and primary aerosols which allows for examination of the evolution of OOA components alone in the Van Krevelen space. This provides a unique means of following ambient secondary OA evolution that is analogous to and can be compared with trends observed in chamber studies of secondary organic aerosol formation. The triangle plot in $\mathrm{Ng}$ et al. (2010) indicates that $f_{44}$ of OOA components increases with photochemical age, suggesting the importance of acid formation in OOA evolution. Once they are transformed with the new parameterization, the triangle plot of the OOA components from all sites occupy an area in Van Krevelen
\end{abstract}

Correspondence to: M. R. Canagaratna (mrcana@aerodyne.com) space which follows a $\Delta \mathrm{H}: \mathrm{C} / \Delta \mathrm{O}: \mathrm{C}$ slope of $\sim-0.5$. This slope suggests that ambient OOA aging results in net changes in chemical composition that are equivalent to the addition of both acid and alcohol/peroxide functional groups without fragmentation (i.e. C-C bond breakage), and/or the addition of acid groups with fragmentation. These results provide a framework for linking the bulk aerosol chemical composition evolution to molecular-level studies.

\section{Introduction}

The study of organic aerosols (OA) in the atmosphere is challenging due to the large number of molecular species involved and the continuous evolution of OA concentration, composition, and properties (Jimenez et al., 2009). Recently, simplified ways of characterizing the aging of OA in the atmosphere from aerosol mass spectrometer (AMS) datasets have been identified ( $\mathrm{Ng}$ et al., 2010; Heald et al., 2010). Ng et al. (2010) analyzed OA components determined from positive matrix factorization (PMF) analysis of 43 AMS datasets in the Northern hemisphere (unit mass resolution mass spectra, UMR, and high resolution, HR). At most sites, OA could be separated into hydrocarbon-like OA (HOA) and oxygenated OA (OOA), and sometimes other primary components. HOA and OOA are good surrogates for primary $\mathrm{OA}(\mathrm{POA})$ and secondary OA (SOA) under most conditions. OOA can be further deconvolved into semi-volatile OOA (SV-OOA) and low volatility OOA (LV-OOA) (Jimenez et al., 2009).

Published by Copernicus Publications on behalf of the European Geosciences Union. 
OA evolution is characterized in terms of the changing intensities of the two most dominant oxygen-containing ions in the OOA spectra, $m / z 44$ (mostly $\mathrm{CO}_{2}^{+}$in ambient data) and $\mathrm{m} / \mathrm{z} 43$. The $\mathrm{m} / \mathrm{z} 43$ fragment is mainly $\mathrm{C}_{2} \mathrm{H}_{3} \mathrm{O}^{+}$for the OOA component, and $\mathrm{C}_{3} \mathrm{H}_{7}^{+}$for the HOA component. In OOA the $\mathrm{m} / \mathrm{z} 44$ ion is thought to be due mostly to acids (Duplissy et al., 2011) or acid-derived species, such as esters. The $m / z 43$ $\left(\mathrm{C}_{2} \mathrm{H}_{3} \mathrm{O}^{+}\right)$ion is predominantly due to non-acid oxygenates. Both acid and non-acid oxygenates have been observed in ambient OA (Russell et al., 2011; Decesari et al., 2007). When $f_{44}$ (ratio of $m / z 44$ to total signal in the component spectrum) is plotted against $f_{43}$ (defined similarly), all OA components fall within a triangular space (Fig. 1, hereafter referred to as the "triangle plot"). The HOA components have $f_{44}<0.05$; SV-OOA and LV-OOA components concentrate in the lower and upper halves of the triangle, respectively. The base of the triangle encompasses the variability in HOA and SV-OOA composition. This range decreases with increasing $f_{44}$ (O:C ratio), suggesting that the aerosols become more chemically similar with increasing aging, largely independent of the initial source of the material (Jimenez et al., 2009; Ng et al., 2010). Most SOA produced in the laboratory experiments cluster on the lower half of the triangle, indicating that they are not as oxidized as ambient LV-OOA (Ng et al., 2010).

Heald et al. (2010) characterized the evolution of total OA composition using the Van Krevelen diagram (H:C vs. O:C) (Van Krevelen, 1950). In this approach, high resolution mass spectra were analyzed to obtain bulk $\mathrm{H}: \mathrm{C}$ and $\mathrm{O}: \mathrm{C}$ values (Aiken et al., 2007, 2008). HR-AMS field datasets and laboratory studies occupy a narrow range when plotted in the Van Krevelen diagram. The authors reported that all the data cluster along a line with slope $\sim-1$, consistent with simultaneous increases in carbonyl and alcohol moieties, either in separate carbons or due to the addition of carboxylic acid groups. It is suggested that the total OA composition moves along this line with increased aging (Heald et al., 2010).

Total OA composition is driven by several effects, including physical mixing, condensation/evaporation effects, and photochemical transformation. In this manuscript we deconvolve total OA into distinct primary (HOA and others) and secondary (total OOA, SV-OOA, LV-OOA) components and explicitly examine ambient OOA evolution alone in a manner that is analogous to and can be compared with chamber SOA experiments. By deconvolving total OA into different components, we remove physical mixing effects between primary and secondary aerosols which allows for examination of the evolution of OOA components alone. It is noted that some of the OOA evolution may occur through mixing of different types of OOA. Unit mass resolution ambient OOA components from $\mathrm{Ng}$ et al. (2010) are then transformed to the Van Krevelen space using a new parameterization of $\mathrm{H}: \mathrm{C}$ in terms of $f_{43}$ that is derived from and is valid for laboratory SOA and ambient OOA components. The OOA composition at any given site is highly dependent on the meteorology,

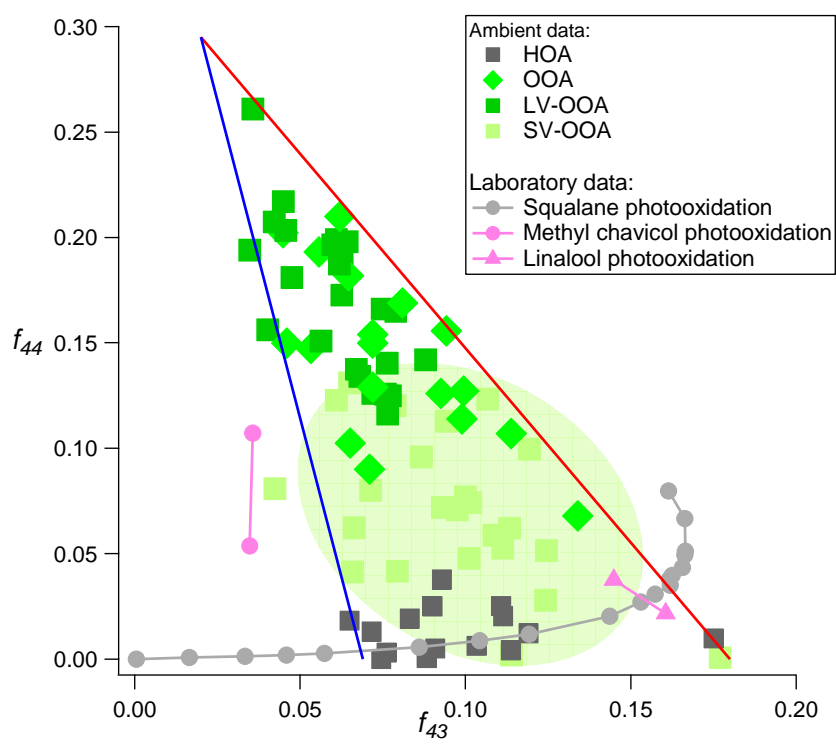

Fig. 1. Triangle plot ( $f_{44}$ vs. $\left.f_{43}\right)$ for all the OOA components from 43 ambient AMS datasets as well as selected laboratory data (adapted from $\mathrm{Ng}$ et al., 2010). The light green shaded area indicates the region where most of laboratory data fall into. It is noted that $f_{43}$ refers to ratio of total $m / z, 43\left(\mathrm{C}_{3} \mathrm{H}_{7}^{+}\right.$and $\left.\mathrm{C}_{2} \mathrm{H}_{3} \mathrm{O}^{+}\right)$to total signal in the component spectrum for the components. The only exception to this are the squalane data (Kroll et al., 2009). The squalane data points were obtained by heterogeneous oxidation and thus $f_{43}$ contains contribution from both unreacted squalane as well as oxidized squalane products. In order to follow the production of the oxidized materials, we only show the ratio of $\mathrm{C}_{2} \mathrm{H}_{3} \mathrm{O}^{+}$to to-

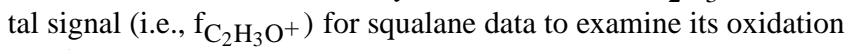
trends.

photochemical aging, and different precursor sources affecting that site. Each component provides a "snapshot" of the OOA as it is formed and aged in the atmosphere, but together the components from multiple worldwide sites define a continuum of OOA properties (Ng et al., 2010; Morgan et al., 2010). We use this integrated analysis of OOA components to examine the trends in Van Krevelen space and the implied changes in chemical composition of ambient OOA evolution.

In this work, we link the complementary information of the triangle plot and the Van Krevelen diagram to provide further understanding of atmospheric OA evolution. The triangle plot provides an empirical way of viewing all new AMS data in the context of available data for characterizing aerosol aging; data obtained from both UMR (such as the Q-AMS and the recently developed Aerosol Chemical Speciation Monitor, ACSM, Ng et al., 2011) and HR instruments can be readily plotted in real time in this space. With detailed data processing of HR-AMS data, the added chemical insight contained in the Van Krevelen diagram provides information on the mechanism of evolution of OA composition. 


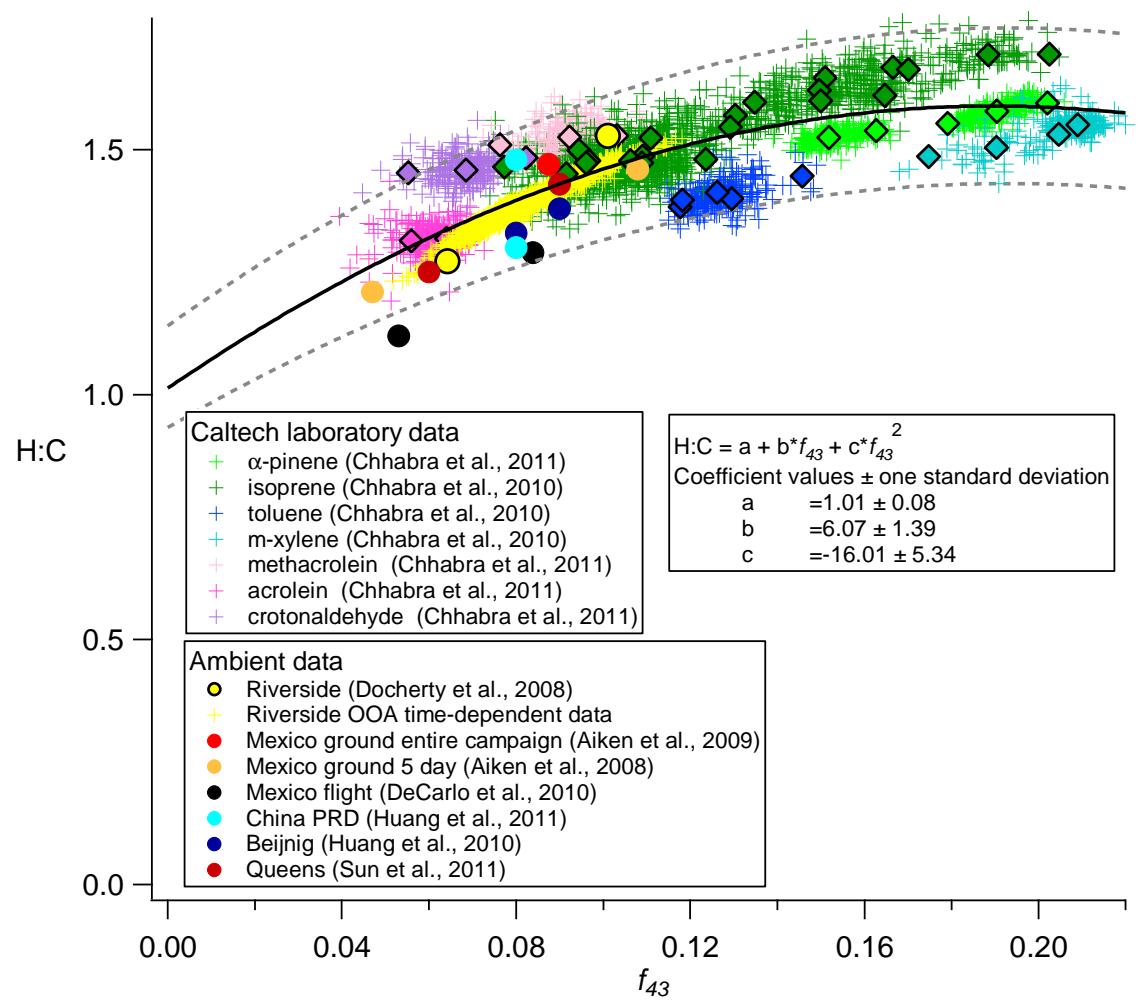

Fig. 2. Parameterization of $\mathrm{H}: \mathrm{C}$ in terms of $f_{43}$ for SOA/OOA, using OOA components (total OOA, SV-OOA, LV-OOA) obtained from PMF analysis of HR-AMS ambient datasets and SOA formed in laboratory studies. It is noted that multiple experiments were performed for each SOA precursor in the laboratory studies. The solid diamonds are the binned laboratory data. The dotted gray lines are $\pm 10 \%$ from the fitted line.

\section{Methods: parameterization of $\mathrm{H}: \mathrm{C}$ vs. $f_{43}$}

In order to map data from the triangle plot ( $f_{44}$ vs. $f_{43}$ ) onto the Van Krevelen diagram (H:C vs. O:C), both $\mathrm{H}: \mathrm{C}$ and $\mathrm{O}: \mathrm{C}$ must be parameterized using UMR data. Aiken et al. (2008) showed that O:C of ambient OA can be estimated from $f_{44}$ through a linear parameterization. In this work, we obtain an analogous parameterization of $\mathrm{H}: \mathrm{C}$ in terms of $f_{43}$ (Fig. 2) for SOA/OOA, using OOA components obtained from PMF analysis of HR-AMS ambient datasets (Docherty et al., 2008; Aiken et al., 2009; DeCarlo et al., 2010; Huang et al., 2011, 2010; Sun et al., 2011) and SOA formed in laboratory studies (Chhabra et al., 2010, 2011). The data used in the parameterization has similar $f_{43}$ range as those observed in ambient OOA components (Fig. 1). It is noted that multiple experiments were performed for each SOA precursor in the laboratory studies. All the data shown are HR, in which $\mathrm{H}: \mathrm{C}$ is determined explicitly by elemental analysis. As these are OOA/SOA data, $f_{43}$ in Fig. 2 is dominated by the oxygenated fragment at $m / z 43$, i.e., $\mathrm{C}_{2} \mathrm{H}_{3} \mathrm{O}^{+}$. The laboratory chamber studies encompass a wide range of precursors (anthropogenic and biogenic) (Chhabra et al., 2010, 2011). Measured O:C is well parameterized in terms of the ion at $m / z 44$, which accounts for much of the measured oxygen in
OOA. For the H:C parameterization, we explored the use of $m / z 43$, which is the next most intense ion in OOA component spectra. While the ion at $m / z 43$ does not necessarily contain a large fraction of measured total hydrogen in OOA, it does correlate well with $\mathrm{H}: \mathrm{C}$ as shown in Fig. 2. In this case, $m / z 43$ functions as a tracer for $\mathrm{H}: \mathrm{C}$ analogous to the use of $f_{60}$ (fraction of $m / z 60$ to the total signal in the mass spectrum) as a tracer for biomass burning organic aerosols (BBOA) (e.g., Cubison et al., 2011), even if the $m / z 60$ ion usually represents a small fraction of the actual BBOA.

The laboratory data are time-dependent data (continuous data over the course of each experiment) and account for more points in Fig. 2 than the ambient data. The variability in the chamber data points reflects precursor-dependent differences in SOA. In order to weight the laboratory data equally with ambient data, for each laboratory experiment the $f_{43}$ values are binned with an $f_{43}$ increment of 0.02 and the average values for $\mathrm{H}: \mathrm{C}$ and $f_{43}$ are calculated for each bin. The binned averages from each experiment are then used in the parameterization. While both linear and polynomial fits reproduce all the data (both binned laboratory and ambient data) to within $10 \%$ uncertainly, the polynomial fit is chosen as it reproduces the ambient data better and captures the curvature of the ambient data at lower $f_{43}$ values. 


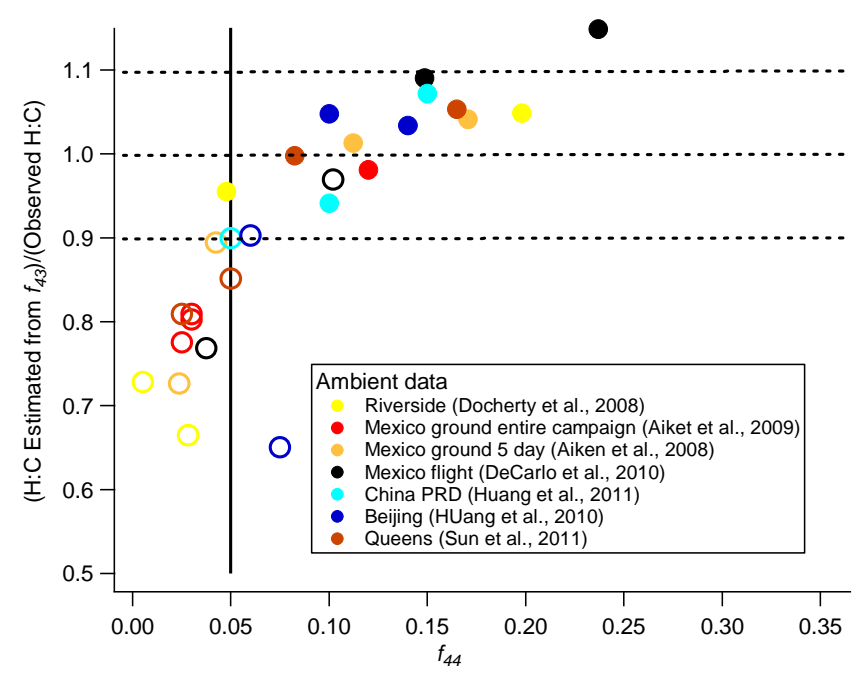

Fig. 3. Ratio of (estimated $\mathrm{H}: \mathrm{C}) /($ observed $\mathrm{H}: \mathrm{C})$ vs. $f_{44}$ for ambient HR-AMS data (where $\mathrm{H}: \mathrm{C}$ can be determined directly). The solid circles are OOA components and the open circles are HOA and other primary OA components (local OA, LOA, biomass burning $\mathrm{OA}, \mathrm{BBOA}$, and cooking $\mathrm{OA}, \mathrm{COA})$. It is clear that for $f_{44}>0.05$, the parameterization shown in Fig. 2 can reproduce the observed $\mathrm{H}: \mathrm{C}$ of the OOA components to within $\pm 10 \%$.

A more detailed evaluation of the linear vs. polynomial fit can be found in the Supplement. The polynomial fit has an intercept of 1.01, indicative of the H:C composition of SOA species likely to yield $f_{43}=0$ under low and high oxidation conditions. The ion at $m / z 43$ can arise from either $\mathrm{C}_{3} \mathrm{H}_{7}^{+}$ (from alkyl groups) or $\mathrm{C}_{2} \mathrm{H}_{3} \mathrm{O}^{+}$(from non-acid oxygenates) fragments. At low levels of oxidation, the most likely SOA hydrocarbon skeleton that can yield $f_{43}=0$ is an aromatic skeleton without large alkyl groups. Simple aromatics without large alkyl groups have $\mathrm{H}: \mathrm{C}$ around 1 . At high levels of oxidation, $m / z 43$ and $m / z 44$ are the most prominent peaks in SOA spectra and the $m / z 44$ to $m / z 43$ ratio increases with aging ( $\mathrm{Ng}$ et al., 2010). The ion $\mathrm{m} / \mathrm{z} 44$ is thought mostly due to acids (Duplissy et al., 2011). Hence, highly aged SOA is likely to have $f_{43}=0$ only if its acid content is high. The species with the highest acid content observed in the aerosol phase is oxalic acid ( $\mathrm{HOOCCOOH})$, which has an H:C of 1 (Kroll et al., 2011). As seen in Fig. 3, the $\mathrm{H}: \mathrm{C}$ of the OOA components $\left(f_{44}>0.05\right)$ are reproduced to within $\pm 10 \%$. It appears that the HOA and other OA components (local OA (LOA), biomass burning OA (BBOA), cooking $\mathrm{OA}(\mathrm{COA})$ ) where $\mathrm{C}_{3} \mathrm{H}_{7}^{+}$contributes $>\sim 20 \%$ of $\mathrm{m} / z 43$ and/or $f_{44}<0.05$ may require a separate parameterization (Fig. S4) and warrants future investigation. Thus, we have not derived $\mathrm{H}: \mathrm{C}$ values for these primary components from $f_{43}$.

\section{Results and discussion}

\subsection{Field measurements}

The OOA components in the triangle plot are transformed into the Van Krevelen diagram using the new parameterization, and the results are shown in Fig. 4. The left and right sides of the triangle plot become the bottom and top lines in the Van Krevelen diagram, respectively. The light green points are SV-OOA which has lower O:C, while the dark green data are LV-OOA which has higher O:C. We refer to Fig. 4 as the "VK-triangle" diagram. Histograms showing the distribution of the estimated $\mathrm{H}: \mathrm{C}$ ratios and the carbon oxidation states $\left(\overline{\mathrm{OS}}_{\mathrm{C}} \approx 2 \mathrm{O} / \mathrm{C}-\mathrm{H} / \mathrm{C}\right.$ ) (Kroll et al., 2011) observed across multiple sites are shown in Fig. 5a and b, respectively. Carbon oxidation state is found to be a useful metric for describing the chemistry of atmospheric organic aerosol (Kroll et al., 2011). SV-OOA components have higher H:C and lower oxidation states than LV-OOA components for almost all sites, with the separation being clearer for the oxidation state. These results are consistent with the distributions of O:C for the different components (Jimenez et al., 2009). Within each category some variation is observed, reflecting the diversity of sources and degrees of aging observed in different field sites. For datasets for which only total OOA was retrievable, its properties lie in between those of SV-OOA and LV-OOA. The variation in $f_{43}$ of the SV-OOA components in the triangle plot is still preserved in the VK-triangle diagram, with SV-OOA components spanning a range of $\mathrm{H}: \mathrm{C}$ ratios. Possible reasons for the range of observed $\mathrm{H}: \mathrm{C}$ ratios include the different SOA precursor mixes and chemical pathways of SOA formation. For instance, the chamber data from photooxidation of methyl chavicol $\left(\mathrm{C}_{10} \mathrm{H}_{12} \mathrm{O}\right)$ and linalool $\left(\mathrm{C}_{10} \mathrm{H}_{18} \mathrm{O}\right)$ span the base of the triangle plot (Fig. 1); these data roughly define the intercepts of the two lines that made up the VK-triangle, which is consistent with the $\mathrm{H}: \mathrm{C}$ ratios of the precursor hydrocarbons (i.e. $\mathrm{H}: \mathrm{C}=1.2$ for methyl chavicol, $\mathrm{H}: \mathrm{C}=1.8$ for linalool).

Heald et al. (2010) examined the evolution of total OA by using the average OA composition at each site and observed a slope of $\sim-1$. Total OA evolution is affected by several factors including physical mixing and processes such as oxidation, volatilization, and condensation. In this work, by deconvolving the total $\mathrm{OA}$ into different components, we are able to separate out the effect of HOA and OOA mixing and focus only on the aging of OOA components alone. On average, the transition from less oxidized to more oxidized OOA follows a slope that is shallower than $-1(\sim-0.5)$. In Heald et al. (2010), it is noted that the slope of the Mexico City aircraft data (DeCarlo et al., 2010) levels off at higher oxidation. The leveling off of the total OA slope at higher O:C, when the OOA fraction of OA is highest, is consistent with the overall trend observed for OOA components alone in this study. 


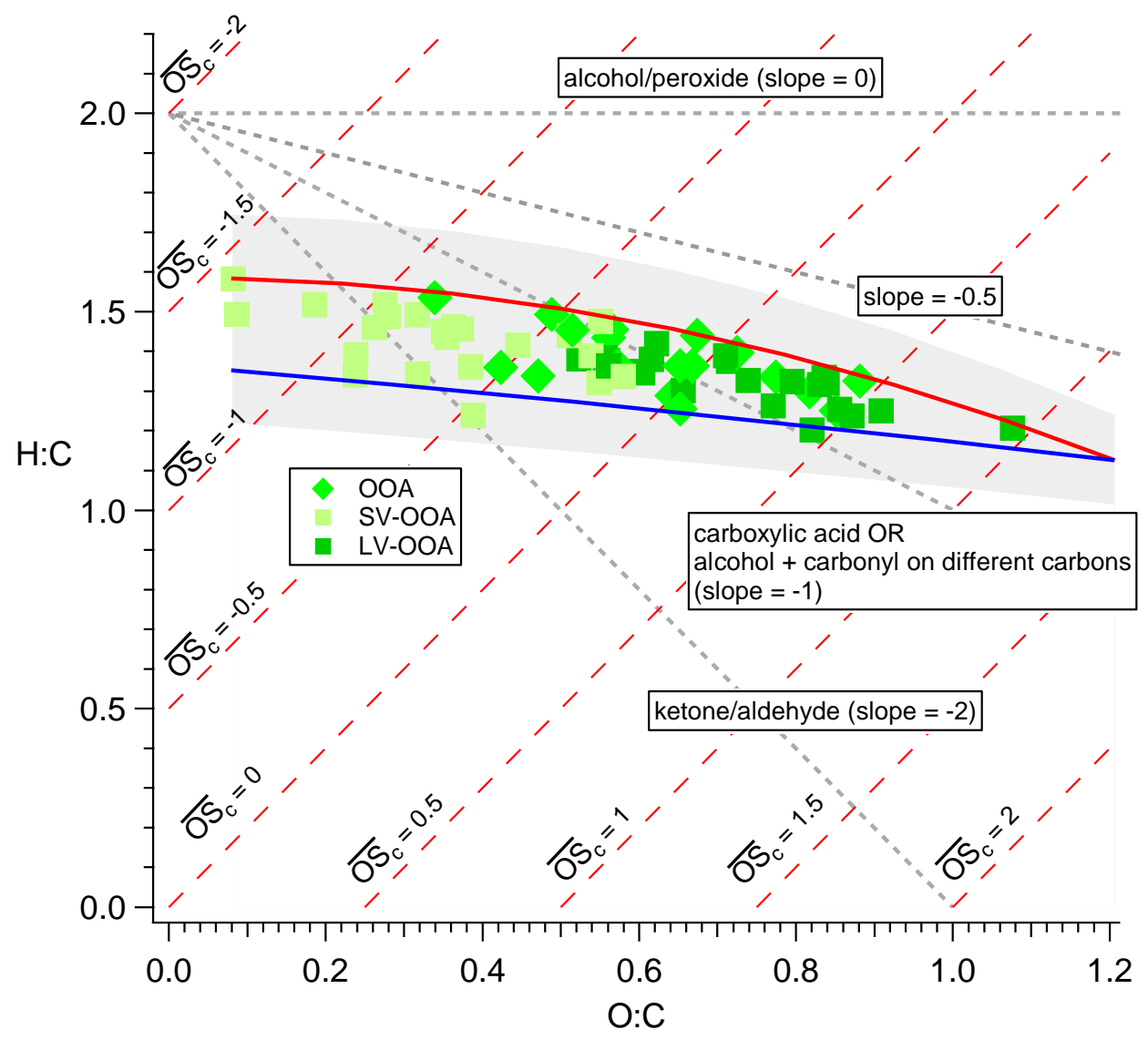

Fig. 4. Representation of all the OOA components into the VK-triangle diagram. The left and right sides of the triangle plot become the bottom and top lines in the Van Krevelen diagram, respectively. The light gray shaded region denotes the $\pm 10 \%$ uncertainty in the parameterization. The estimated carbon oxidation states $\left(\overline{\mathrm{OS}}_{\mathrm{C}} \approx 2 \mathrm{O} / \mathrm{C}-\mathrm{H} / \mathrm{C}\right)$ are shown with the red dotted lines.
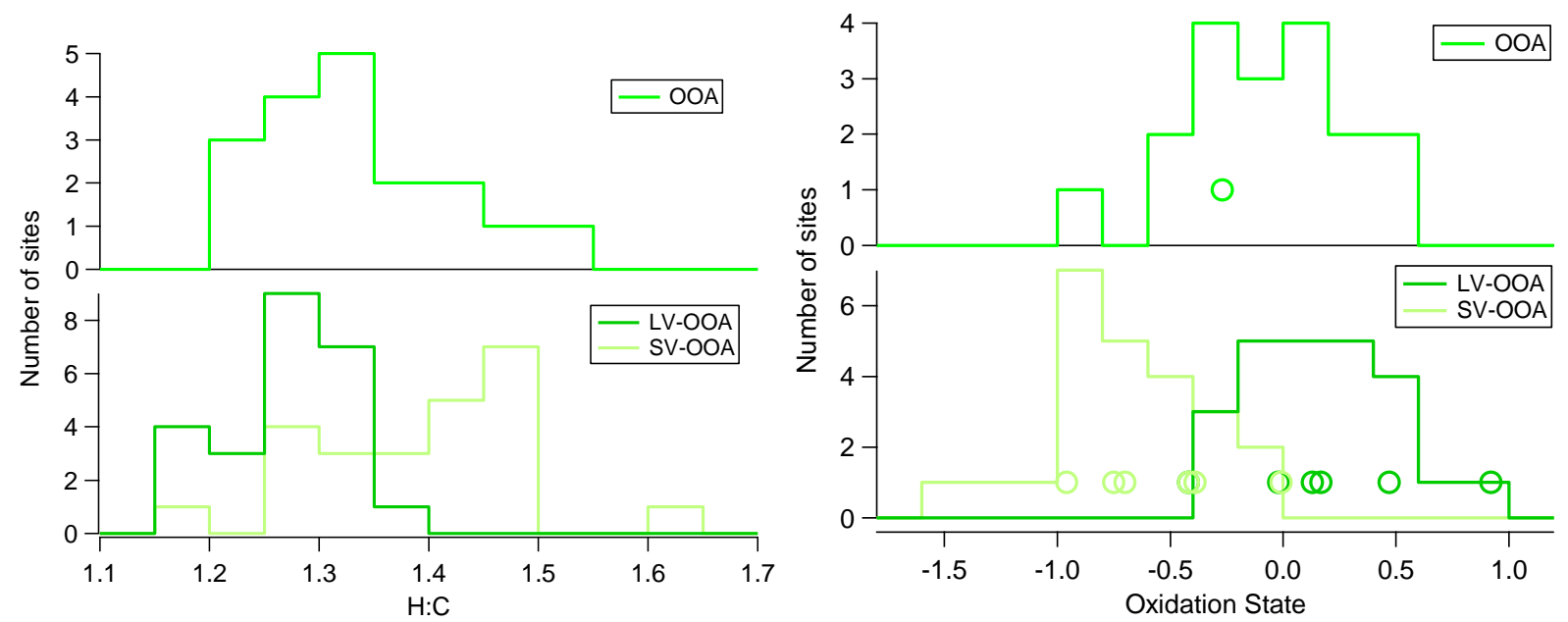

Fig. 5. (a) Histogram showing the distribution of the estimated $\mathrm{H}: \mathrm{C}$ ratios observed across multiple sites. (b) Histogram showing the distribution of the estimated oxidation states $\left(\overline{\mathrm{OS}}_{\mathrm{C}} \approx 2 \mathrm{O} / \mathrm{C}-\mathrm{H} / \mathrm{C}\right)$ observed across multiple sites. The open circles are HR-AMS ambient data in which oxidation state are directly calculated from the data. 


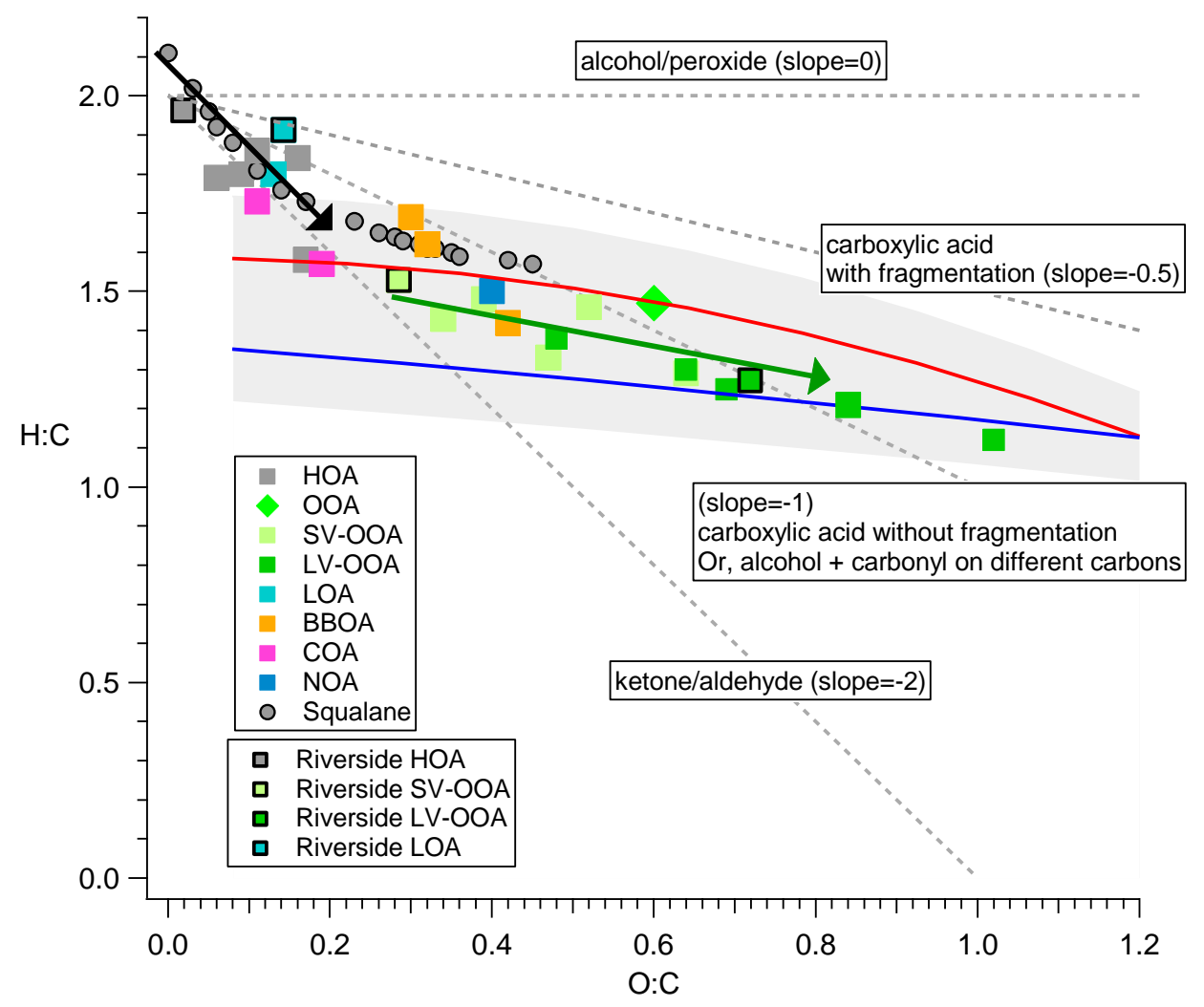

Fig. 6. VK-triangle diagram for the OA components from all sites with HR-AMS data and results from the heterogeneous oxidation of squalane. The light gray shaded region denotes the $\pm 10 \%$ uncertainty in the parameterization. (Note: $\mathrm{LOA}=\mathrm{local} \mathrm{OA}$; $\mathrm{BBOA}=$ biomass burning $\mathrm{OA} ; \mathrm{COA}=$ cooking $\mathrm{OA} ; \mathrm{NOA}=$ nitrogen-enriched $\mathrm{OA})$.

Other than Mexico City (flight and ground) (Aiken et al., 2009; DeCarlo et al., 2010), the OA components from other HR datasets (Riverside, Queens NY, China PRD, Beijing) (Docherty et al., 2008, Sun et al., 2011; Huang et al., 2011, 2010) have also become available recently. The OA components from all these sites and the results from the heterogeneous oxidation of squalane (Kroll et al., 2009) are shown in Fig. 6. The OOA components from these HR datasets mostly fall into the VK-triangle region defined by the UMR data while the HOA and other primary OA components and the squalane data are outside the VK-triangle region. The HOA, SV-OOA, and LV-OOA components from Riverside are highlighted in Fig. 6. Once the total OA is deconvolved into these components, the OOA components in Riverside lie along a shallower slope in the Van Krevelen diagram than the total OA.

The composition differences between primary OA components (HOA, LOA, BBOA, COA) shown in Fig. 6 could reflect some information about the atmospheric evolution of POA, but are not easily interpretable since they also likely represent differences in the initially emitted POA. However, the squalane data suggest that the initial heterogeneous oxidation of POA species may follow a steeper slope, consistent with carbonyl group addition. This corresponds to the horizontal movement of the squalane data across the triangle plot (Fig. 1), with larger increase in $f_{43}$ due to additional $\mathrm{C}_{2} \mathrm{H}_{3} \mathrm{O}^{+}$from non-acid oxygenates (such as carbonyls) and a relatively small increase in $f_{44}$ (acids). Freshly formed SOA, represented by SV-OOA, evolves in a different way, with a shallower slope of $\sim-0.5$. It is possible that further aging of oxidized HOA which has reached the SV-OOA region of the VK-triangle may also proceed with the shallower slope, as hinted by the change in slope of the evolution of squalane oxidation products in Fig. 6. However, this is not definitive from the available ambient data.

An increase in O:C in the Van Krevelen diagram is equivalent to a movement up the triangle plot (increase in $f_{44}$ ). Since $m / z 44$ is found to be proportional to the acid content of standard compounds (Duplissy et al., 2011), it is likely that acid group formation plays an important role in the aging of OOA. Addition of carboxylic acid groups alone corresponds to a Van Krevelen slope of -1 . However, a shallower slope of $\sim-0.5$ in the Van Krevelen diagram is consistent with at least two systematic OOA chemical transformations mechanisms that involve formation of acid groups. If the functional group addition occurs on a $\mathrm{CH}_{2}$ group without $\mathrm{C}-\mathrm{C}$ bond 


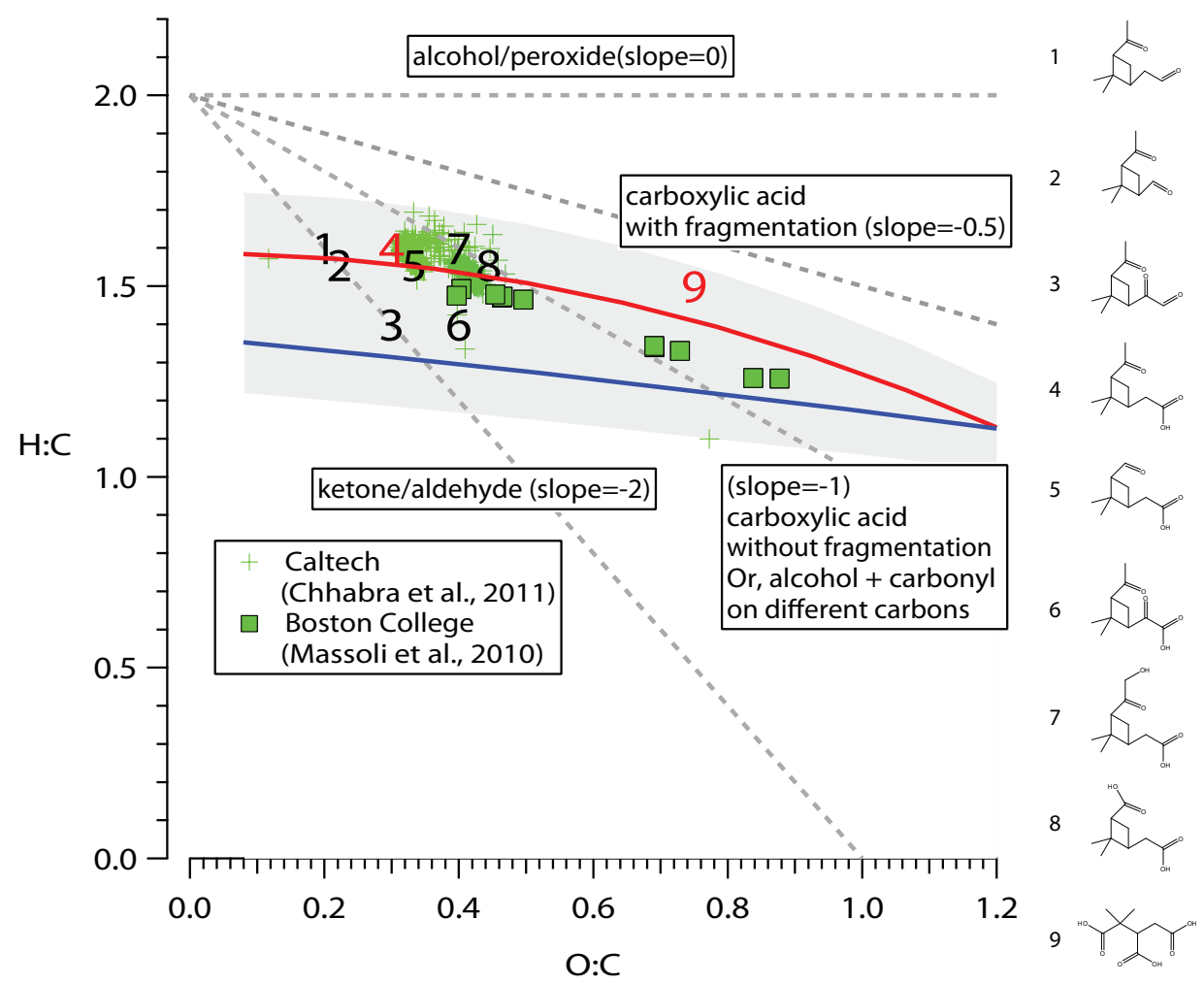

Fig. 7. VK-triangle diagram for $\alpha$-pinene photooxidation, including HR-AMS data from both chamber and flow tube experiments. The light gray shaded region denotes the $\pm 10 \%$ uncertainty in the parameterization. The numbers correspond to individual molecular products in $\alpha$-pinene SOA, with their structures being shown on the right. It is noted that the increasing number correlates with higher O:C and higher generation of oxidation, but it does not represent literally the order in a reaction chain.

breakage, this slope can be caused by e.g., the addition of 3 $\mathrm{OH}$ groups and $1 \mathrm{C}=\mathrm{O}$ group or the addition of $2 \mathrm{OH}$ groups and $1 \mathrm{COOH}$ group. If formation of peroxide is involved, the slope can arise from the addition of $1 \mathrm{OOH}$ group, $1 \mathrm{OH}$ group, and $1 \mathrm{C}=\mathrm{O}$ group, or the addition of $1 \mathrm{OOH}$ group and $1 \mathrm{COOH}$ group. Formation of peroxides would be expected if aging proceeds under low- $\mathrm{NO}_{\mathrm{x}}$ conditions (e.g., Surratt et al., 2006). Furthermore, hydroperoxides react readily with aldehydes (and with ketones under acidic conditions) to form peroxyhemiacetals (and peroxyacetals) (Johnson et al., 2004, 2005), which could also explain the additional of carbonyl groups. Therefore, an OOA aging mechanism that is consistent with measurements (laboratory + field data) is that the ensemble average of the transformation involves both the net addition of $\mathrm{COOH}$ and $\mathrm{OH} / \mathrm{OOH}$ functional groups. An alternative explanation for a slope of -0.5 is due to $\mathrm{COOH}$ group addition to the site of a $\mathrm{C}-\mathrm{C}$ bond cleavage. For instance, the replacement of a $-\mathrm{CH}_{2}$ group with a $-\mathrm{COOH}$ group at a C-C bond breakage (without loss of oxygen during the fragmentation process) will result in a slope of -0.5 in the Van Krevelen diagram. Fragmentation is thought to become increasingly important for already oxidized material such as fresh SOA (Kroll et al., 2009, 2011).

\subsection{Laboratory data}

Photooxidation of $\alpha$-pinene provides a laboratory case study to illustrate aerosol composition changes in the VK-triangle space for a simpler, globally important, and well-studied SOA system (Fig. 7). The data shown in Fig. 7 include HR-AMS data from both chamber and flow tube experiments (Chhabra et al., 2011; Massoli et al., 2010). In the chamber experiments, typical atmospheric $\mathrm{OH}$ levels are employed for hours, resulting in moderate oxidation, i.e. O:C $\sim 0.3$ in the $\mathrm{SV}-\mathrm{OOA}$ range. $\mathrm{OH}$ exposures in the flow tube experiments are much higher and lead to highly oxidized aerosols (in the LV-OOA range, with an O:C up to $\sim 1$ ). Taken together, the chamber and flow tube data map out the entire oxidation range of $\alpha$-pinene SOA and span the whole range of O:C observed in ambient measurements. The oxidation of $\alpha$-pinene follows a slope of $\sim-0.5$ in the Van Krevelen diagram, consistent with the observed evolution of SV-OOA to LV-OOA in ambient data. The slope for the chamber $\alpha$-pinene photooxidation data alone is -0.64 . It is noted that results from laboratory studies of other precursors also have slopes shallower than the slope of -1 expected for acid group addition alone (Chhabra et al., 2011; Lambe et al., 2011). Also shown in Fig. 7 are individual compounds (with known H:C 
and O:C) that have been identified in $\alpha$-pinene SOA (Jaoui and Kamens, 2001; Szmigielski et al., 2007), including both first-generation and higher generation oxidation products. On average, the composition change based on these identified products follows a slope of $\sim-0.5$, consistent with the change in bulk composition measured by the HRAMS. For example, cis-pinonic acid $\left(\mathrm{C}_{10} \mathrm{H}_{16} \mathrm{O}_{3}\right)$ is a typical first-generation product, and its $\mathrm{OH}$ oxidation product, $\alpha, \alpha$ dimethyltricarballylic acid $\left(\mathrm{C}_{8} \mathrm{H}_{12} \mathrm{O}_{6}\right)$, is a tricarboxylic acid formed via fragmentation (Szmigielski et al., 2007). The oxidation of pinonic acid to $\alpha, \alpha$-dimethyltricarballylic acid follows a line with a slope of $\sim-0.5$. Furthermore, it can be seen from the molecular structures that while the cispinonic acid to $\alpha, \alpha$-dimethyltricarballylic acid transformation involves the loss of 2 carbons, there is a net gain of both $\mathrm{OH}$ and $\mathrm{COOH}$ functionalities (possibly through the loss of a carbonyl group to the $\mathrm{C}_{2}$ fragment followed by the addition of two COOH groups) (Szmigielski et al., 2007), consistent with our hypotheses for the dominant chemical transformations in OOA aging. Further molecular-level studies of SOA aging are needed to elucidate the details within these trends.

\section{Conclusions}

By parameterizing organic aerosol $\mathrm{H}: \mathrm{C}$ of SOA/OOA in terms of $f_{43}$, we are able to transform OOA components in the triangle plot ( $f_{44}$ vs. $\left.f_{43}\right)$ into the Van Krevelen diagram (H:C vs. O:C). Ambient OOA components in the triangle plot map out a triangular space in Van Krevelen diagram, showing a range of $\mathrm{H}: \mathrm{C}$ at lower oxidization; such variation decreases with increasing oxidation. Taking all the UMR and HR-AMS OOA components together, it is found that on average, the change in the bulk composition of OOA with aging follows a line with a slope $\sim-0.5$. The triangle plot indicates that as OOA components age, their $f_{44}$, an indicator of acid $(\mathrm{COOH})$ or acid-derived groups, increases. The observed OOA slope of $\sim-0.5$ is consistent with several simple mechanisms such as the net addition of both $\mathrm{COOH}$ and $\mathrm{OH} / \mathrm{OOH}$ functional groups without fragmentation (i.e. $\mathrm{C}-\mathrm{C}$ bond cleavage), and/or the addition of $\mathrm{COOH}$ groups with fragmentation. Aerosol aging can proceed through various pathways including condensation/evaporation, oxidation, particle-phase reactions, and mixing of different air masses. While our results remove the contribution from mixing between OOA and primary OA components, they do not allow us to discriminate between the other aging pathways; the general trends in OOA aging obtained in this study could, however, provide useful constraints for models that explicitly investigate the relative importance of these processes together in the overall evolution of SOA. This work also provides ambient composition information that is analogous to and can be compared with trends observed in chamber studies of SOA formation and detailed molecular-level studies.

\section{Supplementary material related to this article is available online at: http://www.atmos-chem-phys.net/11/6465/2011/ acp-11-6465-2011-supplement.pdf.}

Acknowledgements. We thank grants from DOE (BER, ASR program) DEFG0208ER64627, NOAA NA08OAR4310565, and NSF ATM-0919189. We thank Paola Massoli for sharing the Boston College flow tube data and Jesse Kroll for helpful discussions. We thank the two anonymous reviewers for their helpful comments.

Edited by: M. C. Facchini

\section{References}

Aiken, A. C., DeCarlo, P. F., and Jimenez, J. L.: Elemental Analysis of Organic Species with Electron Ionization HighResolution Mass Spectrometry, Anal. Chem., 79, 8350-8358, doi:8310.1021/ac071150w, 2007.

Aiken, A. C., DeCarlo, P. F., Kroll, J. H., Worsnop, D. R., Huffman, J. A., Docherty, K. S., Ulbrich, I. M., Mohr, C., Kimmel, J. R., Sueper, D., Sun, Y., Zhang, Q., Trimborn, A., Northway, M., Ziemann, P. J., Canagaratna, M. R., Onasch, T. B., Alfarra, M. R., Prevot, A. S. H., Dommen, J., Duplissy, J., Metzger, A., Baltensperger, U., and Jimenez, J. L.: O/C and OM/OC ratios of primary, secondary, and ambient organic aerosols with high-resolution time-of-flight aerosol mass spectrometry, Environ. Sci. Technol., 42, 4478-4485, 2008.

Aiken, A. C., Salcedo, D., Cubison, M. J., Huffman, J. A., DeCarlo, P. F., Ulbrich, I. M., Docherty, K. S., Sueper, D., Kimmel, J. R., Worsnop, D. R., Trimborn, A., Northway, M., Stone, E. A., Schauer, J. J., Volkamer, R. M., Fortner, E., de Foy, B., Wang, J., Laskin, A., Shutthanandan, V., Zheng, J., Zhang, R., Gaffney, J., Marley, N. A., Paredes-Miranda, G., Arnott, W. P., Molina, L. T., Sosa, G., and Jimenez, J. L.: Mexico City aerosol analysis during MILAGRO using high resolution aerosol mass spectrometry at the urban supersite (T0) - Part 1: Fine particle composition and organic source apportionment, Atmos. Chem. Phys., 9, 66336653, doi:10.5194/acp-9-6633-2009, 2009.

Chhabra, P. S., Flagan, R. C., and Seinfeld, J. H.: Elemental analysis of chamber organic aerosol using an aerodyne high-resolution aerosol mass spectrometer, Atmos. Chem. Phys., 10, 4111-4131, doi:10.5194/acp-10-4111-2010, 2010.

Chhabra, P. S., Ng, N. L., Canagaratna, M. R., Corrigan, A. L., Russell, L. M., Worsnop, D. R., Flagan, R. C., and Seinfeld, J. H.: Elemental composition and oxidation of chamber organic aerosol, Atmos. Chem. Phys. Discuss., 11, 10305-10342, doi:10.5194/acpd-11-10305-2011, 2011.

Cubison, M. J., Ortega, A. M., Hayes, P. L., Farmer, D. K., Day, D., Lechner, M. J., Brune, W. H., Apel, E., Diskin, G. S., Fisher, J. A., Fuelberg, H. E., Hecobian, A., Knapp, D. J., Mikoviny, T., Riemer, D., Sachse, G. W., Sessions, W., Weber, R. J., Weinheimer, A. J., Wisthaler, A., and Jimenez, J. L.: Effects of aging on organic aerosol from open biomass burning smoke in aircraft and lab studies, Atmos. Chem. Phys. Discuss., 11, 12103-12140, doi:10.5194/acpd-11-12103-2011, 2011. 
DeCarlo, P. F., Ulbrich, I. M., Crounse, J., de Foy, B., Dunlea, E. J., Aiken, A. C., Knapp, D., Weinheimer, A. J., Campos, T., Wennberg, P. O., and Jimenez, J. L.: Investigation of the sources and processing of organic aerosol over the Central Mexican Plateau from aircraft measurements during MILAGRO, Atmos. Chem. Phys., 10, 5257-5280, doi:10.5194/acp-10-52572010, 2010.

Decesari, S., Mircea, M., Cavalli, F., Fuzzi, S., Moretti, F., Tagliavini, E., and Facchini, M. C.: Source attribution of watersoluble organic aerosol by nuclear magnetic resonance spectroscopy, Environ. Sci. Technol., 41, 2479-2484, 2007.

Docherty, K. S., Stone, E. A., Ulbrich, I. M., DeCarlo, P. F., Snyder, D. C., Schauer, J. J., Peltier, R. E., Weber, R. J., Murphy, S. M., Seinfeld, J. H., Grover, B. D., Eatough, D. J., and Jiimenez, J. L.: Apportionment of Primary and Secondary Organic Aerosols in Southern California during the 2005 Study of Organic Aerosols in Riverside (SOAR-1), Environ. Sci. Technol., 42, 7655-7662, 2008.

Duplissy, J., DeCarlo, P. F., Dommen, J., Alfarra, M. R., Metzger, A., Barmpadimos, I., Prevot, A. S. H., Weingartner, E., Tritscher, T., Gysel, M., Aiken, A. C., Jimenez, J. L., Canagaratna, M. R., Worsnop, D. R., Collins, D. R., Tomlinson, J., and Baltensperger, U.: Relating hygroscopicity and composition of organic aerosol particulate matter, Atmos. Chem. Phys., 11, 1155-1165, doi:10.5194/acp-11-1155-2011, 2011.

Heald, C. L., Kroll, J. H., Jimenez, J. L., Docherty, K. S., DeCarlo, P. F., Aiken, A. C., Chen, Q., Martin, S. T., Farmer, D. K., and Artaxo, P.: A simplified description of the evolution of organic aerosol composition in the atmosphere, Geophys. Res. Lett., 37, L08803, doi:08810.01029/02010GL042737, 2010.

Huang, X.-F., He, L.-Y., Hu, M., Canagaratna, M. R., Sun, Y., Zhang, Q., Zhu, T., Xue, L., Zeng, L.-W., Liu, X.-G., Zhang, Y.-H., Jayne, J. T., Ng, N. L., and Worsnop, D. R.: Highly time-resolved chemical characterization of atmospheric submicron particles during 2008 Beijing Olympic Games using an Aerodyne High-Resolution Aerosol Mass Spectrometer, Atmos. Chem. Phys., 10, 8933-8945, doi:10.5194/acp-10-8933-2010, 2010.

Huang, X.-F., He, L.-Y., Hu, M., Canagaratna, M. R., Kroll, J. H., Ng, N. L., Zhang, Y.-H., Lin, Y., Xue, L., Sun, T.-L., Liu, X.-G., Shao, M., Jayne, J. T., and Worsnop, D. R.: Characterization of submicron aerosols at a rural site in Pearl River Delta of China using an Aerodyne High-Resolution Aerosol Mass Spectrometer, Atmos. Chem. Phys., 11, 1865-1877, doi:10.5194/acp-11-18652011, 2011.

Jaoui, M. and Kamens, R. M.: Mass balance of gaseous and particulate products analysis from $\alpha$-pinene/ $\mathrm{NO}_{\mathrm{x}} /$ air in the presence of natural sunlight, J. Geophys. Res.-Atmos., 106, 12541-12558, 2001.

Jimenez, J. L., Canagaratna, M. R., Donahue, N. M., Prevot, A. S. H., Zhang, Q., Kroll, J. H., DeCarlo, P. F., Allan, J. D., Coe, H., Ng, N. L., Aiken, A. C., Docherty, K. S., Ulbrich, I. M., Grieshop, A. P., Robinson, A. L., Duplissy, J., Smith, J. D., Wilson, K. R., Lanz, V. A., Hueglin, C., Sun, Y. L., Tian, J., Laaksonen, A., Raatikainen, T., Rautiainen, J., Vaattovaara, P., Ehn, M., Kulmala, M., Tomlinson, J. M., Collins, D. R., Cubison, M. J., Dunlea, E. J., Huffman, J. A., Onasch, T. B., Alfarra, M. R., Williams, P. I., Bower, K., Kondo, Y., Schneider, J., Drewnick, F., Borrmann, S., Weimer, S., Demerjian, K., Salcedo, D., Cot- trell, L., Griffin, R., Takami, A., Miyoshi, T., Hatakeyama, S., Shimono, A., Sun, J. Y., Zhang, Y. M., Dzepina, K., Kimmel, J. R., Sueper, D., Jayne, J. T., Herndon, S. C., Trimborn, A. M., Williams, L. R., Wood, E. C., Middlebrook, A. M., Kolb, C. E., Baltensperger, U., and Worsnop, D. R.: Evolution of Organic Aerosols in the Atmosphere, Science, 326, 1525-1529, 2009.

Johnson, D., Jenkin, M. E., Wirtz, K., and Martin-Reviejo, M.: Simulating the formation of secondary organic aerosol from the photooxidation of toluene, Environ. Chem., 1, 150-165, 2004.

Johnson, D., Jenkin, M. E., Wirtz, K., and Martin-Reviejo, M.: Simulating the formation of secondary organic aerosol from the photooxidation of aromatic hydrocarbons, Environ. Chem., 2, 3548, 2005.

Kroll, J. H., Smith, J. D., Che, D. L., Kessler, S. H., Worsnop, D. R., and Wilson, K. R.: Measurement of fragmentation and functionalization pathways in the heterogeneous oxidation of oxidized organic aerosol, Phys. Chem. Chem. Phys., 11, 8005-8014, 2009.

Kroll, J. H., Donahue, N. M., Jimenez, J. L., Kessler, S. H., Canagaratna, M. R., Wilson, K. R., Altieri, K. E., Mazzoleni, L. R., Wozniak, A. S., Bluhm, H., Mysak, E. R., Smith, J. D., Kolb, C. E., and Worsnop, D. R.: Carbon oxidation state as a metric for describing the chemistry of atmospheric organic aerosol, Nat. Chem., 3, 133-139, doi:110.1038/NCHEM.1948, 2011.

Lambe, A. T., Onasch, T. B., Massoli, P., Croasdale, D. R., Wright, J. P., Ahern, A. T., Williams, L. R., Worsnop, D. R., Brune, W. H., and Davidovits, P.: Laboratory studies of the chemical composition and cloud condensation nuclei $(\mathrm{CCN})$ activity of secondary organic aerosol (SOA) and oxidized primary organic aerosol (OPOA), Atmos. Chem. Phys. Discuss., 11, 1361713653, doi:10.5194/acpd-11-13617-2011, 2011.

Massoli, P., Lambe, A. T., Ahern, A. T., Williams, L. R., Ehn, M., Mikkila, J., Canagaratna, M. R., Brune, W. H., Onasch, T. B., Jayne, J. T., Petaja, T., Kulmala, M., Laaksonen, A., Kolb, C. E., Davidovits, P., and Worsnop, D. R.: Relationship between aerosol oxidation level and hygroscopic properties of laboratory generated secondary organic aerosol (SOA) particles, Geophys. Res. Lett., 37, L24801, doi:24810.21029/22010GL045258, 2010.

Morgan, W. T., Allan, J. D., Bower, K. N., Highwood, E. J., Liu, D., McMeeking, G. R., Northway, M. J., Williams, P. I., Krejci, R., and Coe, H.: Airborne measurements of the spatial distribution of aerosol chemical composition across Europe and evolution of the organic fraction, Atmos. Chem. Phys., 10, 4065-4083, doi:10.5194/acp-10-4065-2010, 2010.

Ng, N. L., Canagaratna, M. R., Zhang, Q., Jimenez, J. L., Tian, J., Ulbrich, I. M., Kroll, J. H., Docherty, K. S., Chhabra, P. S., Bahreini, R., Murphy, S. M., Seinfeld, J. H., Hildebrandt, L., Donahue, N. M., DeCarlo, P. F., Lanz, V. A., Prévôt, A. S. H., Dinar, E., Rudich, Y., and Worsnop, D. R.: Organic aerosol components observed in Northern Hemispheric datasets from Aerosol Mass Spectrometry, Atmos. Chem. Phys., 10, 46254641, doi:10.5194/acp-10-4625-2010, 2010.

Ng, N. L., Herndon, S. C., Trimborn, A., Canagaratna, M. R., Croteau, P., Onasch, T. M., Sueper, D., Worsnop, D. R., Zhang, Q., Sun, Y. L., and Jayne, J. T.: An Aerosol Chemical Speciation Monitor (ACSM) for routine monitoring of atmospheric aerosol composition, Aerosol Sci. Technol., 45, 770-784, 2011.

Russell, L. M., Bahadur , R., and Ziemann, P. J.: Identifying organic aerosol sources by comparing functional group composition in 
chamber and atmospheric particles, Proc. Natl. Acad. Sci. USA, 108, 3516-3521, doi:10.1073/pnas.1006461108, 2011.

Sun, Y.-L., Zhang, Q., Schwab, J. J., Demerjian, K. L., Chen, W.N., Bae, M.-S., Hung, H.-M., Hogrefe, O., Frank, B., Rattigan, O. V., and Lin, Y.-C.: Characterization of the sources and processes of organic and inorganic aerosols in New York city with a high-resolution time-of-flight aerosol mass apectrometer, Atmos. Chem. Phys., 11, 1581-1602, doi:10.5194/acp-11-15812011, 2011.

Surratt, J. D., Murphy, S. M., Kroll, J. H., Ng, N. L., Hildebrandt, L., Sorooshian, A., Szmigielski, R., Vermeylen, R., Maenhaut, W., Claeys, M., Flagan, R. C., and Seinfeld, J. H.: Chemical composition of secondary organic aerosol formed from the photooxidation of isoprene, J. Phys. Chem. A, 110, 9665-9690, 2006.
Szmigielski, R., Surratt, J. D., Gomez-Gonzalez, Y., Van der Veken, P., Kourtchev, I., Vermeylen, R., Blockhuys, F., Jaoui, M., Kleindienst, T. E., Lewandowski, M., Offenberg, J. H., Edney, E. O., Seinfeld, J. H., Maenhaut, W., and Claeys, M.: 3-methyl1,2,3-butanetricarboxylic acid: An atmospheric tracer for terpene secondary organic aerosol, Geophys.Res. Lett., 34, L24811, doi:24810.21029/22007GL031338, 2007.

Van Krevelen, D. W.: Graphical-statistical method for the study of structure and reaction processes of coal, Fuel, 24, 269-284, 1950. 